\title{
THE INVESTIGATIONS ON THE IMPACT OF THE OXYGEN HYPERBARY ON THE IMMUNOLOGIC RESPONSE OF THE ORGANISM
}

\author{
BADANIA NAD WPEYWEM HIPERBARII TLENOWE] NA REAKCJE IMMUNOLOGICZNE USTROJU
}

ИССЛЕДОВАНИЯ НАД ВЛИЯНИЕМ ГИПЕРБАРИЧЕСКОЙ ОКСИГЕНАЦИИ НА

ИММУНОЛОГИЧЕСКИЕ РЕАКЦИИ СИСТЕМЫ

\section{ERforschung des EINFLUSSES VON AEROBEM HYPERBaRISMUS GUF IMMUNREAKTIONEN IM KÖRPER}

\section{ESTUDIOS SOBRE LOS EFECTOS DE LA HIPERBARIA DE OXIGENO EN LAS REACCIONES DEL SISTEMA INMUNITARIO}

\author{
Kazimierz Ulewicz \\ Department of Maritime Medicine of the Military Medical Academy
} Katedra Medycyny Morskiej WAM

\section{StREsZCZENIA / ABStRACTS}

Knowledge of the impact of hyperbaric conditions, especially hyperbaric oxygen, on human and animal organisms, is of great theoretical and practical importance, particularly in reference to the increased application of hyperbaric oxygen for therapeutic purposes.

It must be said that unfortunately our knowledge on the impact of hyperbaria, including oxygen hyperbaria, on the immunological response of the animal and human organisms is still not sufficient and is incomplete. The Institute of the Naval Medicine of the Naval Academy in Gdynia has been carrying out tests in this field for some years now. The tests have been carried out on animals (rabbits, guinea pigs) as well as on humans (commercial divers, scuba divers, and candidates to these activities) within immunology investigations. The impact of hyperbaric oxygen at pressures ranging between 2.8 and 3.1 ata, in single or multiple expositions, have been tested as well as the relations between hyperbaria in air and the different conditions of the exposure. The study revealed important shifts in the immunological response of both the animals and humans.

Keywords: hyperoxia, immunity, hyperbaric, complement, opsonic index.

Znajomość zagadnienia wpływu hiperbarii tlenowej na ustrój ludzki i zwierzęcy posiada duże znaczenie teoretyczne i praktyczne. Wynika to z faktu, że hiperbaria tlenowa znajduje coraz szersze zastosowanie $w$ leczeniu różnych chorób. Niestety nasza wiedza na temat wpływu hiperbarii, w tym hiperbarii tlenowej, na reakcje immunologiczne organizmu ludzkiego i zwierzęcego jest w dalszym ciągu niewystarczająca i niepełna. Instytut Medycyny Morskie Wojskowej Akademii Medycznej w Gdyni od kilku lat prowadzi badania poświęcone tej dziedzinie. W ramach badań w zakresie immunologii prowadzone sa eksperymenty z udziałem zwierząt (króliki, świnki morskie) i ludzi (nurkowie i kandydaci na nurków). Wpływ hiperbarii tlenowej w przedziale ciśnień od 2,8 do 3,1 ata badany jest podczas ekspozycji jednorazowych i wielokrotnych. Badanie ujawniło istotne zmiany w odpowiedzi immunologicznej zarówno u zwierząt, jak i u ludzi.

Słowa kluczowe: hiperoksja, odporność, hiperbaria, dopełniacz, indeks opsoninowy.

ARTICLE INFO

PolHypRes 2017 Vol. 61 Issue 4 pp. 49 - 54

ISSN: 1734-7009 eISSN: 2084-0535

DOI: $10.1515 / \mathrm{phr}-2017-0022$

Pages: 6, figures: 0, tables: 2

page $w w w$ of the periodical: www.phr.net.pl

Publisher

Polish Hyperbaric Medicine and Technology Society
Typ artykułu: oryginalny

Original article

Przygotowany do druku w 1976 r.

Przyjęto do druku w PHR 19.04.2017r 
Знание положений о влиянии гипербарической оксигенации на организм человека и животных имеет большое теоретическое и практическое значение. Это следует из того факта, что кислородная оксигенация находит широкое применение в лечении различных заболеваний. К сожалению, наши знания на тему влияния гипербарии, в том числе гипербарической оксигенации, на иммунологические реакции организма человека и животных по-прежнему остаются недостаточными и неполными. Институт морской медицины Военной медицинской академии в Гдыне уже несколько лет проводит исследования в этой области. В рамках исследований по иммунологии проводятся эксперименты с участием животных (кролики, морские свинки) и людей (ныряльщики и кандидаты на ныряльщиков). Влияние гипербарической оксигенации в диапазоне давления от 2,8 до 3,1 ata исследуется при единовременной или многократной экспозиции. Исследование показало существенные изменения в иммунологическом ответе, как у животных, так и у людей.

Ключевые слова: гипероксия, сопротивляемость, гипербария, комплемент, опсонический индекс.

Das Wissen über den Einfluss von Sauerstoffhyperbarismus auf das menschliche und tierische System ist von großer theoretischer und praktischer Bedeutung. Dies ergibt sich aus der Tatsache, dass aerobe Hyperbarie bei der Behandlung von verschiedenen Krankheiten zunehmend breitere Anwendung findet. Leider ist unser Wissen über den Einfluss von Hyperbarismus, einschließlich aeroben Hyperbarismus, auf die immunologischen Reaktionen des menschlichen und tierischen Körpers immer noch unzureichend und unvollständig. Das Institut für Meeresmedizin der Militärakademie in Gdynia forscht seit mehreren Jahren auf diesem Gebiet. Die Untersuchungen auf dem Gebiet der Immunologie umfassen Experimente mit Tieren (Kaninchen, Meerschweinchen) und Menschen (Taucher und Tauchanwärter). Die Wirkung von Sauerstoff-Überdruck im Druckbereich von 2,8 bis 3,1 ata wird bei Einzel- und Mehrfachbelastungen getestet. Die Studie zeigte signifikante Veränderungen in der Immunantwort bei Tieren und Menschen. Schlüsselwörter: Hyperoxie, Resistenz, Hyperbarie, Komplement, Opsonin-Index.

El conocimiento sobre los efectos de la hiperbaria de oxígeno sobre el sistema inmunitario humano y animal es de gran importancia teórica y práctica. Esto se debe al hecho de que la hiperbaria de oxígeno se utiliza cada vez más en el tratamiento de diversas enfermedades. Por desgracia, nuestro conocimiento sobre el impacto de la hiperbaria, incluyendo la hiperbaria de oxígeno, sobre la respuesta inmunológica del organismo humano y animal es todavía insuficiente e incompleto. El Instituto de Medicina Marina de la Academia Médica Militar de Gdynia lleva varios años investigando en este campo. Como parte de la investigación sobre inmunología, se llevan a cabo experimentos con animales (conejos, conejillos de indias) y humanos (buzos y candidatos a buzos). Los efectos de la hiperbaria de oxígeno con un rango de presión de entre 2,8 a 3,1 ata se estudian en exposiciones simples y múltiples. El estudio ha revelado cambios significativos en la respuesta inmunológica tanto en animales como en humanos.

Palabras clave: hiperoxia, inmunidad, hiperbaria, complemento, índice de opsonina. 


\section{WSTĘP}

Znajomość zagadnienia wpływu hiperbarii tlenowej na ustrój ludzkich i zwierzęcy posiada duże znaczenie teoretyczne i praktyczne. Wynika to z faktu, że hiperbaria tlenowa znajduje między innymi coraz szersze zastosowanie w leczeniu różnych chorób. Ponadto istnieje możliwość zastosowania hiperbarii tlenowej do produkcji dopełniacza, który jest szeroko stosowany w odczynie wiązania dopełniacza w pracowniach bakteriologicznych, immunologicznych czy wirusologicznych $[5,6]$.

Odpowiednio udokumentowane spostrzeżenia i badania doświadczalne wskazują, że hiperbaria tlenowa zależnie od wartości nadcisnienia i czasu ekspozycji, jak również sposobu stosowania, wywiera wpływ na układ nerwowy, układ sercowo-naczyniowy, krwiotwórczy oddechowy, narząd wzroku, na metabolizm komórkowy a ponadto na układ immunologiczny oraz odporność. Należy dodać że dane na temat wpływu hiperbarii, w tym i hiperbarii tlenowej na układ immunologiczny i odporność są jeszcze skąpe, a nasze wiadomości na ten temat niewystarczające i $\mathrm{w}$ wielu wypadkach sprzeczne $[3,4,7,8]$.

W Instytucie Medycyny Morskiej WAM od szeregu lat prowadzi się badania nad wpływem hiperbarii w tym hiperbarii tlenowej na reakcję immunologiczne człowieka i zwierząt. Omawiając te badania $\mathrm{w}$ konfrontacji $\mathrm{z}$ nielicznymi danymi piśmiennictwa należy stwierdzić, że porównywanie wyników badań $\mathrm{z}$ tego zakresu oraz ich interpretacja napotyka $\mathrm{w}$ wielu przypadkach na trudności ze względu na często niewystarczająco opisywane warunki doświadczeń, metodykę, a ponadto ze względu na trudności $\mathrm{w}$ organizacji tych badań, ograniczenia stosowania eksperymentów i tym podobne.

Dodatkowe trudności powoduje fakt, że badając wpływ hiperbarii na ustrój nurka czy płetwonurka pod wodą, czy w komorze ciśnieniowej należy uwzględnić cały zespół czynników tutaj działających (ciśnienie hydrostatyczne, ciśnienie parcjalne poszczególnych składników gazowych, czas, oziębienie, wysiłek pod wodą, czy w hiperbarii w komorze, charakter ekspozycji i tak dalej) przy czym wpływ ich na poszczególnych osobników może być różny.

W zakresie wpływu hiperbaroksji na reakcje immunologiczne ustroju człowieka czy zwierzęcia stałocieplnego należy uwzględnić poszczególne elementy wczesnej i późnej odpowiedzi immunologicznej ustroju, to jest humoralnej i komórkowej, zaś w zakresie wpływu tego czynnika na odporność jego działanie na poszczególne rodzaje drobnoustrojów zarówno $\mathrm{w}$ doświadczeniach in vitro, jak $\mathrm{i}$ in vivo, na ich metabolizm, odporność na wpływy otoczenia, fazę produkcji antygenów, oraz na czynniki działające w organizmie człowieka czy zwierzęcia, jak wreszcie na warunki rozwoju drobnoustrojów w tkankach i komórkach organizmu. Stąd też wpływ ten musi być rozpatrywany bardzo wnikliwie i szeroko a wnioski podawane ostrożnie.

Celem badań było określenie wpływu hiperbarii tlenowej na odpowiedź immunologiczną. Badania prowadzono zarówno na zwierzętach, jak i z udziałem ludzi.

\section{INTRODUCTION}

Knowledge of the influence of oxygen hyperbaria on the human and animal system is of great theoretical and practical importance. This is due to the fact that hyperbaric oxygenation is finding an increasingly broader application in the treatment of various diseases. In addition, it is possible to use hyperbaric oxygenation for complement production, a product which is widely used in complement fixation tests in bacteriological, immunological or virological laboratories $[5,6]$.

Properly documented observations and experimental studies indicate that hyperbaric oxygenation, depending on the overpressure value and exposure time, as well as the mode of application, affects the nervous system, cardiovascular system, haematopoietic respiratory system, the organs of the visual system, cellular metabolism and, moreover, the immunological system and immunity. It should be added that data on the influence of hyperbaria, including hyperbaric oxygenation, on the immunological system and immunity are still scarce, and that furthermore, the information obtained by us regarding this subject matter is insufficient and in many cases contradictory $[3,4,7,8]$.

The Institute of Maritime Medicine has been conducting research on the influence of hyperbaria, including oxygen hyperbaria, on the immunological reactions of humans and animals for several years. When discussing this research in confrontation with the limited data which is available from literature, it is noted that upon comparison and interpretation of the research results from this field, in many cases one encounters difficulties due to the often inadequately described experimental conditions, methodology, and also because of the difficulty in organising these studies, the imposed restrictions on the use of experiments, and the like.

Additional difficulties result from the fact that when investigating the influence of hyperbaria on the diver's body, while under water or in a pressure chamber, it is necessary to consider an entire combination of factors (hydrostatic pressure, partial pressure of particular gaseous components, time, cooling, effort made while under water or in a hyperbaric chamber, the nature of the exposure, etc.), as well as keep in mind that their impact may vary in each individual case. When considering the influence of hyperbaroxia on the immunological reactions of a human, or any other warmblooded animal, one should take into consideration particular elements of an early and late response of the immunological system, i.e. humoral and cellular response.

Whereas when it comes to the impact of this factor on immunity it is necessary to analyse its effect on various types of microorganisms during both in vitro and in vivo experiments with regard to their metabolism, resistance to environmental influences, the phase of production of antigens, and factors acting in the human or animal body, and finally on the conditions for the development of microorganisms in the tissues and cells of the body. Hence, this influence needs to be examined very carefully and broadly, and the conclusions must be drawn cautiously.

The aim of the study was to determine the effect of oxygen hyperbaria on the immunological response. The research was carried out both on animals and humans. 


\section{MATERIAŁ I METODY}

W zakresie wpływu hiperbarii tlenowej na reakcje immunologiczne ustroju ludzkiego określano średni poziom dopełniacza w surowicy krwi określany metodą 50\% hemolizy.

W badaniu wzięło udział 133 mężczyzn w wieku 18 - 25 lat, żołnierzy i marynarzy. Podzielono ich na następujące grupy:

I - kandydaci na nurków wojskowych - 51 osób poddanych 60-o minutowej powietrznej ekspozycji hiperbarycznej do nadciśnienia 2,8 ata

II - kandydaci na nurków wojskowych - 15 osób poddanych 60-o minutowej normobarycznej ekspozycji tlenowej.

III - nurkowie wojskowi - 32 osoby poddane 60o minutowej powietrznej ekspozycji hiperbarycznej do nadciśnienia 2,8 ata

IV - kontrolna - 35 osób; marynarzy i kandydatów na nurków, nie poddawanych żadnym procedurom.

Krew dobadania pobierano $\mathrm{z}$ żyły łokciowej bezpośrednio przed ekspozycją; „pomiar 0”, 72 godziny po ekspozycji „pomiar 1”, 5 dni po ekspozycji „pomiar 2” i 10 dni po ekspozycji „pomiar 3 ".

W przypadku zwierząt do badania wykorzystano króliki, które uprzednio uodporniono drobnoustrojami S.typhi F7. Oznaczano we krwi zwierząt wartość indeksu opsoninowego.

Zwierzęta podzielono na 3 grupy po 5 zwierząt, razem 15 królików, które poddano jednorazowej 60-cio minutowej ekspozycji hiperbarycznej ze 100\% tlenem jako czynnikiem oddechowym.

Ekspozycje prowadzono w specjalnie skonstruowanej komorze hiperbarycznej dla małych zwierząt. Komora została zaprojektowana w postaci zbiornika ciśnieniowego, hermetycznie zamykanego, o pojemności 30 litrów. Umożliwia ona uzyskiwanie kontrolowanych nadciśnień do 10 atm, a zatem sprężanie zwierząt doświadczalnych, przetrzymanie ich przez dowolny czas $\mathrm{w}$ hiperbarii $\mathrm{z}$ użyciem dowolnych czynników oddechowych a nastepnie powolne lub szybkie rozprężenie.

Zwierzęta grupy A sprężono do ciśnienia 1,8 atm, zwierzęta grupy B do ciśnienia 2,4 atm a zwierzęta grupy C do ciśnienia 3,1 atm. Krew do badania pobierano z żyły brzeżnej ucha bezpośrednio przed ekspozycją, 60 minut po ekspozycji, 24 godziny po ekspozycji, 48 godzin po ekspozycji i 10 dni po ekspozycji.

\section{WYNIKI}

Uzyskane wyniki badań poziomu dopełniacza we krwi badanych nurków przedstawia tabela 1.

\section{MATERIAL AND METHODS}

The effect of oxygen hyperbaria on the immunological reactions of the human organism was determined on the basis of the average complement level in the blood serum using the $50 \%$ haemolysis method.

The study was attended by 133 men aged 18 25 years, soldiers and sailors. They were divided into the following groups:

I - candidates for military divers -51 persons subjected to a 60-minute hyperbaric air exposure to the overpressure of 2.8 ata

II - candidates for military divers - 15 persons subjected to a 60 -minute normobaric oxygen exposure

III - candidates for military divers -32 persons subjected to a 60 -minute hyperbaric air exposure to the overpressure of 2.8 ata

IV - control group - 35 persons; seafarers and diver candidates who were not subject to any procedures.

Blood was collected from the ulnar vein immediately before the exposure; "measurement 0 ", 72 hours after the exposure "measurement 1", 5 days after the exposure "measurement 2 " and 10 days after the exposure "measurement 3 ".

The part of the experiment conducted on animals was performed on rabbits previously immunised with microorganisms S.typhi F7. The value of the opsonic index was determined in the animals' blood.

The animals were divided into 3 groups of 5 animals, in total 15 rabbits, and subjected to a one-time 60 -minute hyperbaric exposure with $100 \%$ oxygen used as the breathing mix.

The exposures were conducted in a specially constructed hyperbaric chamber for small animals. The chamber was designed as a hermetically closed pressure tank with a capacity of 30 liters. The chamber facilitates the selection of controlled pressures of up to $10 \mathrm{~atm}$, and therefore the compression of the experimental animals, maintaining them in hyperbaric conditions for various time spans, as well as a slow or fast decompression.

Group A animals were pressurised to $1.8 \mathrm{~atm}$, group B animals to $2.4 \mathrm{~atm}$ and group C animals to 3.1 atm. The blood for the study was collected from the auricular marginal vein immediately before the exposure, 60 minutes after exposure, 24 hours after the exposure, 48 hours after the exposure and 10 days after the exposure.

\section{RESULTS}

The obtained values of the opsonic index in the divers' blood are presented in Table 1 .

Mean complement activity

Średnia miana aktywności dopełniacza.

\begin{tabular}{|c|c|c|c|c|c|}
\hline & Group size. & Measurement 0 & Measurement 1 & Measurement 2 & Measurement 3 \\
\hline Group I - & 51 & $21.5 \mathrm{u}$. & $27.75 \mathrm{u}$. & $24.55 \mathrm{u}$. & $22 \mathrm{u}$. \\
\hline Grupa II - & 15 & $25.9 \mathrm{u}$. & $25.4 \mathrm{u}$. & $25.9 \mathrm{u}$. & $25.2 \mathrm{u}$. \\
\hline Group III - & 32 & $24.4 \mathrm{u}$. & $23.85 \mathrm{u}$. & $24.2 \mathrm{u}$. & $24 \mathrm{u}$. \\
\hline $\begin{array}{l}\text { Group IV } \\
\text { CONTROL }\end{array}$ & 35 & - & $24.3 \mathrm{u}$. & $23.6 \mathrm{u}$. & $24 \mathrm{u}$. \\
\hline
\end{tabular}

Tab. 1 
W tych badaniach stwierdzono u ludzi, pod wpływem hiperbarii tlenowej w okresie bezpośrednio po i 3-5 dni od ekspozycji wzrost aktywności dopełniacza w surowicy krwi. Widoczna jest także różnica w reakcji ustroju pomiędzy grupami doświadczonych nurków i kandydatów na nurków. W grupie doświadczonych nurków aktywność dopełniacza utrzymuje się na stałym poziomie, podobnie jak w grupie kontrolnej.

Uzyskane wartości indeksu opsoninowego u królików przedstawia tabela 2 .
The studies on humans showed an increase in complement activity in the blood serum immediately after and 3-5 days from the exposure to oxygen hyperbaria. There is also a visible difference in the reaction of the organism between groups of experienced divers and diver candidates. In the group of experienced divers complement activity is maintained at a constant level, similarly to the control group.

The obtained values of the opsonic index in rabbits are shown in table 2 .

Opsonic index values in rabbits.

Wartości indeksu opsoninowego u królików.

\begin{tabular}{|c|c|c|c|c|c|c|c|c|c|c|c|c|c|c|c|c|c|}
\hline & \multicolumn{5}{|c|}{ Animals from group A } & \multicolumn{5}{|c|}{ Animals from group B } & \multicolumn{5}{|c|}{ Animals from group $\mathrm{C}$} & \multicolumn{2}{|c|}{ Statistical analysis } \\
\hline & $\mathrm{I}$ & II & III & IV & $\mathrm{V}$ & $\mathrm{I}$ & II & III & IV & $\mathrm{V}$ & $\mathrm{I}$ & II & III & IV & $\mathrm{V}$ & / & $\begin{array}{l}\mathrm{P}=99.9 \mathrm{t} \\
\text { groups }\end{array}$ \\
\hline before & 0.6 & 0.4 & 0.7 & 0.8 & 1.4 & 0.3 & 0.3 & 0.5 & 0.5 & 0.7 & 0.7 & 0.4 & 0.6 & 0.6 & 0.5 & 0.26 & \\
\hline $60^{\prime}$ & 4.8 & 2.3 & 2.3 & 2.8 & 2.3 & 0.5 & 2.8 & 3.8 & 2.1 & 4.5 & 1.6 & 3.0 & 2.0 & 2.8 & 2.3 & 2.661 .08 & $7.1 \mathrm{t}$ \\
\hline $24 \mathrm{~h}$ & 1.5 & 2.0 & 3.8 & 2.3 & 2.3 & 1.1 & 3.0 & 3.1 & 2.5 & 4.6 & 1.8 & 4.1 & 3.0 & 4.3 & 3.8 & 2.890 .99 & $8.5 \mathrm{t}$ \\
\hline $48 \mathrm{~h}$ & 1.8 & 3.0 & 4.6 & 2.3 & 2.1 & 1.8 & 3.3 & 3.1 & 1.8 & $\mathrm{X}^{1}$ & 2.3 & 3.1 & 3.0 & 4.1 & 3.1 & 2.810 .82 & $9.3 \mathrm{t}$ \\
\hline 10 days & 1.1 & 1.0 & 0.8 & 1.5 & 2.0 & 2.3 & 0.8 & 1.1 & 1.0 & 1.1 & 1.3 & 0.8 & 1.3 & 2.3 & 1.3 & 1.310 .50 & $5.0 \mathrm{t}$ \\
\hline
\end{tabular}

W badaniach na królikach, pod wpływem hiperbarii tlenowej $\mathrm{w}$ okresie 3-5 dni od ekspozycji stwierdzono wzrost indeksu opsoninowego, zwłaszcza u osobników którzy uprzednio nie stykali się z czynnikiem uodparniającym.

\section{DYSKUSJA}

W innych badaniach stwierdzano spadek czy przy niższych wartościach nadciśnienia tendencję spadku swoistych antystreptolizyn 0 , aglutynin, szczególnie dla antygenów rzęskowych S.typhi, S.typhi murium (mniej dla antygenów somatycznych), spadek hemaglutinin oraz częściowy spadek immunoglobulin IgG, mniej IgA, IgM przy normalizacji w czasie 10 do 15 dni $[3,6,11]$.

W szeregu wypadków, zwłaszcza w odniesieniu do aglutynin, hemaglutinin oraz immunoglobulin obserwowano odchylenia, co należy tłumaczyć należy indywidualnymi różnicami osobniczymi. U świnek morskich obserwowano np. w tych warunkach również znamienny wzrost aktywności dopełniacza w czasie 3-5 dni od ekspozycji.

Tego rodzaju przesunięcia w zakresie wymienionych wskaźników immunologicznych obserwowano już przy jednorazowej ekspozycji 60 minutowej na hiperbarię tlenową w zakresie nadciśnień od 0,588 ata do 2,8 ata. Te przeciwstawne w zakresie wymienionych czynników immunologicznych przesunięcia należałoby tłumaczyć tym, że badane czynniki immunologiczne odmiennie reagują na podrażnienie układu nerwowego wegetatywnego pod wpływem bodźca hiperbarii tlenowej w pierwszym okresie stresowej reakcji alarmowej.

Przy ekspozycji hiperbarycznej z użyciem tlenu jako czynnika oddechowego dochodzi do podrażnienia układu wegetatywnego sympatergicznego, co prowadzi do wzrostu aktywności dopełniacza w surowicy krwi i wzrostu indeksu opsoninowego, a tym samym
The studies on rabbits showed an increase in the opsonic index in the period of 3-5 days following the exposure, particularly in specimens that had not been previously exposed to the immunising agent.

\section{DISCUSSION}

Other studies demonstrated that with lower overpressure values there is a decrease or a downward trend in specific antistreptolysins 0 , particularly for flagellar antigens S. typhi, S. typhi murium (less for somatic antigens), also there is a noted haemagglutinin drop and partial decrease of IgG, less IgA, IgM in the normalisation in the period of 10 to 15 days $[3,6,11]$.

In a number of cases, especially with regard to agglutinins, haemagglutinins and immunoglobulins, deviations were observed, which we believe should be accounted for as natural variances between individuals. In these conditions, for example, guinea pigs showed a significant increase in complement activity within 3-5 days from the exposure.

Such shifts in the scope of the above-mentioned immunological indicators were observed already after a single 60-minute exposure to oxygen hyperbaria in the overpressure range between 0.588 ata and 2.8 ata. These displacements, in the field of the aforementioned immunological factors, could be explained by the fact that the studied immunological factors react differently to irritation of the vegetative nervous system under the influence of stimulus in the form of oxygen hyperbaria in the first period of a stress alarm reaction.

During a hyperbaric exposure with the use of oxygen as a breathing mix, the sympathetic vegetative system is irritated which leads to an increase in complement activity in the blood serum and the opsonic index, thus suppressing the reaction of the cholinergic vegetative system, which results in a decrease or sometimes a downward trend in the content of 
przytłumienia reakcji układu wegetatywnego cholinergicznego, co pociąga za sobą spadek czy niekiedy tendencję spadku aglutynin, antystreptolizyn 0 , immunoglobulin IgG, w mniejszym stopniu IgA i IgM. Adaptacja ustroju do hiperbarii tlenowej powstająca w następstwie wielokrotnych ekspozycji nie doprowadza zwykle do tych przesunięć $[3,5,10]$.

Powyższe spostrzeżenia są częściowo potwierdzone $\mathrm{w}$ zakresie obserwacji zmian aglutynacyjny w badaniach innych autorów [1], a łączą się z zaobserwowaną ogólnie wyższą zachorowalność nurków na różne zakażenia $[2,4,9]$.

Opisane spostrzeżenia w zakresie reakcji immunologicznych człowieka i zwierząt pod wpływem hiperbarii $\mathrm{w}$ tym i hiperbarii tlenowej maja istotne znaczenie dla badań nad możliwością leczenia hiperbarią tlenową zakażeń a prawdopodobnie również i zaburzeń odporności immunologicznej. Wymagają jednak dalszych szczegółowych badań $\mathrm{w}$ tym zakresie na odpowiednio licznym i różnorodnym materiale, przy zastosowaniu nowoczesnej metodyki badań. agglutinins, antystreptolysins 0 , IgG immunoglobulins, and to a lesser extent of IgA and IgM. The above shifts are not normally observed following multiple exposures to oxygen hyperbaria, as the organism is known to adapt to this new environment $[3,5,10]$.

The above observations are partially confirmed in the observation of agglutination changes in the studies carried out by other authors [1], and are linked to the observed generally higher incidence of various infections in divers $[2,4,9]$.

The described observations in the area of human and animal immunological responses under the influence of hyperbaria, including hyperbaric oxygenation, are important for the study on the possibility of treating infections with oxygen hyperbaria as well as, presumably, immunological disorders. Nonetheless, they require further detailed research in this respect on a sufficiently broad and diverse material using modern research methodology.

\section{REFERENCES}

Goyne R., Ackerman G.: Aerosp.Med., 1969. 40: 1224-1231;

Gottlieb S.: Ann. Rev. Mikrob., 1971, Vol.25: 111-152;

Doboszyński T., Ulewicz K., Łokucijewski B., Michniewski P.: III Int. Symp. of Mar. Med. Leningrad 1968., Str. ref. 1969: 94 - 98;

Jendyk M., Klinek H.: Lek. Wojsk., 1968, 3: 175-181;

Kierznikowicz B.: The effect of hyperbaric oxygenation on complement activity in the blood of humans and guinea pigs. Doctoral dissertation, Gdynia 1975

6. Kierznikowicz B., Ulewicz K.: About the influence of oxygen hyperbaria on the activity of complement in human'sera - in Acta Physiol. Pol: Ulewicz K.:Ann. Immunol. Hung., 1971. 15: 121-126;

Ulewicz K.: Circulatory and immunological system. In: Zarys fizjopatologii nurkowania. Ed. A. Dolatkowski, K. Ulewicz. PZWL Warsaw 1973;

Ulewicz K., Filipek B.:Med.eLav. 1970. 34: 63-70;

10. Ulewicz K., Michniewski P., Kierznikowicz B.: Biul. WAM., 1971, 2 :207-216;

11. Ulewicz K., Michniewski P.: And. Immunol. Hung., 1971. 15: 129-136. 